\title{
Telaah Kritis Makalah Uji Diagnostik
}

\author{
Alan R. Tumbelaka
}

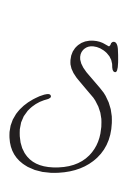

ebagai klinisi, menegakkan diagnosis merupakan bagian terbesar dalam pekerjaan sehari-hari kita. Menyadari betapa seringnya kita harus menegakkan diagnosis sebagai bagian tatalaksana pasien, maka jelas sangat penting bila diagnosis yang tepat dapat ditegakkan. Bila kita menginginkan suatu diagnosis yang berbasis bukti medis, maka beberapa pertanyaan akan timbul, yaitu: ${ }^{1}$

- Bagaimana caranya membuat diagnosis klinis menjadi lebih memiliki basis bukti?

- Bagaimana cara mendapatkan upaya diagnosis yang baik, serta membuktikan kesahihannya berbasis bukti, dan secara tepat mengimplementasikannya pada pasien kita?

- Hal-hal apakah yang diperlukan untuk mampu melakukan prosedur di atas?

Uji diagnostik ataupun penelitian diagnostik bertujuan untuk mengumpulkan informasi untuk memperjelas status kesehatan pasien dengan menggunakan karakteristik pasien, gejala dan tanda, riwayat penyakit, pemeriksaan fisis, pemeriksaan laboratorium dan penunjang lainnya.

Objektif yang ingin dicapai dengan melakukan uji diagnostik adalah, antara lain: ${ }^{2,3}$

- Memperbesar kepastian akan adanya atau tidak adanya suatu penyakit

- Diperlukan kemampuan untuk membedakan keberadaan suatu penyakit yang cukup memadai

- Biasanya kemampuan menduga uji ini diperoleh dari suatu tabel 2 X 2 dengan membandingkan hasil suatu pemeriksaan dengan suatu nilai baku

- Hasil-hasil pengujian beberapa pemeriksaan bisa mirip satu sama lain, tetapi berbeda dalam

\footnotetext{
Alamat Korespondensi:

Dr. Alan R. Tumbelaka, SpA(K).

Subbagian Infeksi dan Penyakit Tropis, Bagian Ilmu Kesehatan Anak FKUI-RSCM, Jl. Salemba no. 6 Jakarta 10430.

Telepon: 391 4126. Fax.: 3907743.
}

ketepatan/akurasi, serta tingkat invasif / risiko pemeriksaan (misalnya: anamnesis terhadap pemeriksaan fisis)

- Menunjang tatalaksana klinik, melalui penetapan keberadaan serta lokasi suatu kelainan dalam memutuskan tindakan yang akan diambil

- Penilaian prognosis, melalui perbandingan hasil pemeriksaan awal dan tindak lanjut

- Penilaian perjalanan penyakit

- Penilaian derajat kesehatan dalam suatu saringan penerimaan pegawai

Rencana pemeriksaan atau penilaian diagnostik harus dilakukan sesuai dengan objektif yang ingin dicapai. Perlu dipertimbangkan kemungkinan ketidaknyamanan ataupun komplikasi akibat perlakuan suatu pemeriksaan diagnostik terhadap pasien. Menilai uji diagnostik yang akan dilakukan dalam suatu tatalaksana kasus memerlukan suatu kemampuan khusus, dan hal ini merupakan inti telaah kritis suatu makalah yang melaporkan hasil penelitian uji diagnostik.

Dalam EBM (Evidence Based Medicine), penilaian suatu makalah / telaah kritis dilakukan melalui suatu sistim yang baku dengan mengacu pada penilaian Validity, Importancy, dan Aplicability hasil penelitian tersebut. ${ }^{1,2}$

\section{Uji diagnostik}

Pada dasarnya suatu uji diagnostik merupakan penelitian observasional yang membandingkan hasil dugaan/prediksi suatu pemeriksaan atau test, terhadap suatu nilai baku yang mendekati kebenaran/gold standard. Seberapa besar hasil pemeriksaan dapat mendekati/menduga nilai sebenarnya akan menentukan besarnya akurasi pemeriksaan tersebut, baik dalam kepastian terdapatnya penyakit ataupun kepastian normal atau tidaknya seseorang. ${ }^{2,3}$

Bentuk dasar analisis uji diagnostik adalah suatu tabel $2 \times 2$ dengan variabel penduga/predictor dan 
variabel hasil akhir/outcome di dalam baris dan kolomnya.

Parameter yang dinilai antara lain: $:^{1,2,4,5}$

1. Pravalensi (P): proporsi orang sakit terhadap semua subjek penelitian

2. Sensitifitas (Se): probabilitas hasil pemeriksaan adalah positif di antara subjek yang sakit

3. Spesifitas (Sp): probabilitas hasil pemeriksaan adalah negatif di antara subjek yang tidak sakit

4. Nilai duga positif (PPV): probabilitas kejadian penyakit pada subjek dengan hasil pemeriksaan positif

5. Nilai duga negatif (NPV): probabilitas tidak adanya penyakit pada subjek dengan hasil pemeriksaan negatif.

6. Likelihood ratio (LR) positif/negatif: perbandingan probabilitas hasil positif/negatif pada subjek sakit dengan probabilitas hasil positif/ negatif pada subjek tidak sakit

Secara umum bentuk hubungan tersebut dinyatakan sebagai berikut:

\begin{tabular}{lccc}
\hline $\begin{array}{l}\text { Pemeriksaan/ } \\
\text { Hasil }\end{array}$ & Sakit & $\begin{array}{c}\text { Tidak } \\
\text { sakit }\end{array}$ & Jumlah \\
\hline Uji positif & $\mathrm{a}$ & $\mathrm{b}$ & $\mathrm{a}+\mathrm{b}$ \\
Uji negatif & $\mathrm{c}$ & $\mathrm{d}$ & $\mathrm{c}+\mathrm{d}$ \\
Jumlah & $\mathrm{a}+\mathrm{c}$ & $\mathrm{b}+\mathrm{d}$ & $\mathrm{a}+\mathrm{b}+\mathrm{c}+\mathrm{d}$ \\
\hline
\end{tabular}

$P=a+c / a+b+c+d$

Se $=a / a+c, S p=d / b+d$

$P P V=a / a+b, N P V=d / c+d$

$\mathrm{LR}+=[\mathrm{a} / \mathrm{a}+\mathrm{c}] /[\mathrm{b} / \mathrm{b}+\mathrm{d}]=\mathrm{Se} /[1-\mathrm{Sp}]$

$\mathrm{LR}-=[\mathrm{c} / \mathrm{a}+\mathrm{c}] /[\mathrm{d} / \mathrm{b}+\mathrm{d}]=[1-\mathrm{Se}] / \mathrm{Sp}$

Diharapkan setiap penilaian uji diagnostik mampu dan mengerti perhitungan parameter uji diagnostik di atas untuk kemudian mampu menilai apakah hasil penelitian itu memenuhi kriteria EBM untuk menunjukkan seberapa besar penelitian tersebut dapat menunjang atau menyingkirkan kemungkinan adanya penyakit.

Dikenal beberapa istilah yang dapat membantu kita dalam menegakkan atau menyingkirkan suatu penyakit, yaitu SpPIn dan SnNOut.

SpPIn: menunjukkan bahwa bila suatu pemeriksaan yang sangat spesifik (Sp tinggi) memberikan hasil positif, maka pemeriksaan itu menunjukkan bahwa si pasien kemungkinan besar menderita (rule in) penyakit itu, sebaliknya

SnNOut: menunjukkan bahwa bila suatu pemeriksaan yang sangat sensitif (Se tinggi) memberikan hasil negatif, maka pemeriksaan itu berhasil menyingkirkan (rule out) adanya penyakit yang diduga. ${ }^{1}$

Dengan menilai LR (likelihood ratio) dari suatu pemeriksaan dengan membandingkan probabilitas suatu hasil di antara subjek sakit dan tidak sakit, dapat dimengerti betapa pentingnya suatu pemeriksaan yang mempunyai nilai LR tinggi. Sebagai contoh, bila probabilitas mendapat hasil positif pada subjek sakit adalah $90 \%$ sedang probabilitas hasil positif pada subjek tidak sakit hanya 10\%, LR+ adalah 90/10 atau 9 , yang berarti kemungkinan menemukan hasil positif adalah 9 kali lipat didapatkan pada subjek sakit daripada tidak sakit. Semakin besar nilai LR+ tersebut, semakin besar kemampuan pemeriksaan tersebut memisahkan subjek sakit dan tidak sakit. Nilai suatu LR dapat dihitung dari pemeriksaan sensitifitas dan spesifisitas. Disebutkan bahwa nilai LR $\geq 10$ dapat meningkatkan pre-test probability menjadi post-test probability adanya penyakit yang sangat bermakna. ${ }^{1,2,3,4}$

Beberapa aspek lain yang perlu mendapat perhatian penting dalam memahami dan menilai hasil penelitian uji diagnostik adalah aspek metodologi penelitian seperti, besar sampel, confidence interval, ketersamaran/ blinding, pre dan posttest probability.

\section{Telaah kritis}

Dalam melakukan telaah kritis terhadap makalah laporan hasil uji diagnostik, diperlukan kemampuan untuk menjawab 3 pertanyaan utama, yaitu: ${ }^{1,4,5}$

1. Apakah bukti tentang akurasi uji/pemeriksaan diagnostik ini sahih/valid?

2. Apakah bukti yang sahih ini dapat menunjukkan penting (important) atau tidaknya pemeriksaan ini dalam memisahkan dengan akurat kasus yang sakit dan tidak sakit?

3. Apakah uji diagnostik yang sahih (valid) dan penting (important) ini dapat diaplikasikan (applicable) pada pasien?

Pertanyaan 1 dan 2 yang mencerminkan kesahihan (validity) dan kepentingan (importancy) suatu hasil penelitian sering disebut sebagai telaah kritis (critical appraisal) dan dapat dilakukan dengan urutan acak. Banyak klinisi lebih menyukai menilai penting atau 
tidaknya suatu hasil penelitian terlebih dahulu ketimbang kesahihannya. Sedang pihak lainnya lebih suka menilai kesahihannya terlebih dahulu, dengan argumen bahwa apalah artinya suatu hasil penelitian bila dilakukan dengan tidak sahih? Pada dasarnya keduanya harus dilakukan sebelum menjawab pertanyaan ke 3, tergantung kemampuan menjawab para penilainya.

Untuk menelaah laporan uji diagnostik secara kritis, beberapa pertanyaan di bawah ini harus dapat dijawab (jawaban dapat berupa YA, TIDAK, TIDAK TAHU dengan alasan dan keterangannya).

\section{A. Validity/Kesahihan}

1. Apakah uji diagnostik dibandingkan secara independen dan tersamar terhadap baku emas (gold standard)?

2. Apakah uji diagnostik dievaluasi pada kelompok pasien yang sesuai dengan populasi

3. Apakah terhadap para subjek pemeriksaandiperlakukan referensi baku apapun hasil pemeriksaannya?

4. Apakah pemeriksaan uji diagnostik ini pernah dilakukan juga pada kelompok lain di luarpenelitian ini?

\section{B. Important/Kepentingan Hasil}

Lakukan perhitungan parameter-parameter uji diagnostik dengan menggunakan tabel $2 \times 2$

- Sensitifitas

- Spesifisitas

- Nilai duga positif dan negatif

- Likelihood ratio positif dan negatif

\section{Applicability}

1. Apakah uji diagnostik ini tersedia, cukup teliti dan tepat untuk digunakan pada pasien kita?

2. Apakah kita mampu meramalkan secara klinis penyakit pasien, berdasarkan:

a. Pengalaman, prevalensi, dan data statistik serta penelitian terdahulu?

b. Apakah data penelitan sesuai kondisi pasien kita?

c. Adakah kemungkinan perubahan kemungkinan sakit/tidak pada pasien kita bila bukti ini dipakai?
3. Apakah nilai posttest probability akan mempengaruhi tatalaksana pasien kita dan menolong pasien tersebut?

a. Apakah kita dapat merubah ambang pemeriksaan - pengobatan?

b. Apakah pasien akan mau mencoba hasil uji tersebut?

c. Apakah konsekuensi pemeriksaan ini akan menolong pasien kita mendapatkan tujuan pemeriksaannya?

\section{Komentar}

Jelas terlihat bahwa ada pemeriksaan yang memiliki sensitifitas yang sangat tinggi, dan hal ini memungkinkan penyingkiran diagnosis (ingat SnNOut) bila hasilnya negatif. Namun demikian bila dilihat $\mathrm{LR}(+)$, maka ternyata nilai tertinggi diperoleh urinalisis yang secara relatif hanya memiliki Se dan Sp 88,6\% dan $88,4 \%$. Jadi, nilai sensitifitas dan spesifisitas saja tidak cukup untuk menyatakan suatu uji diagnostik mempunyai kemampuan tinggi untuk memilah antara sakit dan tidak sakit.

Tindak lanjut telaah kritis ini, berupa penilaian aplikabilitas pemeriksaan urin menggunakan perangkat yang diuji tentunya harus dijawab dengan menilai faktor pasien, dokter, dan perangkat penunjang lainnya.

\section{Kesimpulan}

1. Dalam setiap upaya memperoleh diagnosis yang tepat, pemilihan uji diagnostik perlu dilakukan secara baik, berbasis bukti dan telah ditelaah secara kritis (baik oleh kita sendiri ataupun orang lain).

2. Uji diagnostik bukan dimaksudkan untuk menemukan ketepatan diagnostik secara absolut, melainkan untuk mengurangi ketidakpastian dalam menegakkan diagnosis. Diharapkan dengan mengerti cara menelaah secara kritis suatu laporan uji/riset diagnostik:

a. Kita bisa mengerti perlu atau tidaknya suatu uji diagnostik dalam menunjang tata laksana pasien

b. Kita dapat menerangkan logika probabilitas kejadian suatu penyakit serta batas/ambang penentuan saat perlu tidaknya terapi diasosiasikan 
dengan probabilitas kejadian penyakit

3. Pada saat mengambil keputusan untuk melakukan uji diagnostik, perlu mulai dipikirkan apa yang akan dilakukan bila hasil pengujian diperoleh dan apakah hasil itu akan menolong pasien kita.

\section{Daftar Pustaka}

1. Sackett D. Evidence based medicine: how to practice and teach EBM. Edisi 2 Toronto: Churchill Livingston, 2000.
2. Knottnerus JA, Weel Cv, Muris JWM. Evidence based of clinical diagnosis. Evaluation of diagnostic procedures. BMJ 2002; 324:477-80.

3. Feinstein AR. Misguided efforts and future challenges for research on "diagnostic tests". J Epidemiol Community Health 2002; 56:330-2.

4. Sastroasmoro S. Telaah kritis makalah kedokteran (I). Dalam: Sastroasmoro S, Ismael S, penyunting. Dasar dasar metodologi penelitian klinis, edisi-2. Jakarta: Sagung Seto, 2002. h. 341-44.

5. Sastroasmoro S. Telaah kritis makalah kedokteran (2). Dalam: Sastroasmoro S, Ismael S, penyunting. Dasar dasar metodologi penelitian klinis. Edisi-2. Jakarta: Sagung Seto, 2002. h. 345-64. 